\title{
Tricanter Production Process Optimization by Digital Factory Simulation Tools
}

Jiř́i Kyncl ${ }^{1}$, Tomáš Kellner ${ }^{1}$, Richard Kubiš²

${ }^{1}$ Fakulta strojní, Ústav technologie obrábění, projektování a metrologie, ČVUT v Praze, E-mail: jiri.kyncl@fs.cvut.cz, tomas.kellner@fs.cvut.cz

${ }^{2}$ PBS a.s., E-mail: kubis.r@pbsvb.cz

As a result of globalization the aspects of raising productivity and speed of production with extreme requests on the flexibility of the production systems are gaining importance. These aspects of production are affected by type of product and production and mainly by the capability of companies to correctly manage the manufacturing process. Manufacturing process is globally quicker than it was and the areas of logistics and production planning are still gaining more importance. Gradual changes are also in complexity of production. Without modern tools for production planning it would be very hard to manage production effectively. These tools are part of digital factory concept. Because of those tools the effective planning of production and utilizing the production facilities capacity to its fullest is possible. This paper describes development and implementation of the digital factory concept and its tools in our partner company and is built on previous paper dedicated to common implementation principles of digital factory tools. The main goal of digital factory implementation was optimization of the Tricanter production planning process, elimination of bottle-necks of production system and optimization of manufacturing facilities capacities utilization.

Keywords: Digital Factory Tools, Simulation, Optimization, Production Process Planning, Bottle-Neck Analysis

\section{Acknowledgement}

This work was supported by the governmental funding of Technological Agency of Czech Republic-project number TA04020658.

\section{References}

[1] KYNCL, J. (2016). Digital Factory Simulation Tools. In Manufacturing Technology. Vol. 16, No. 2 , pp.371 - 375. ISSN 1213-2489

[2] BERANEK, L.; VOLF, L. \& MIKES, P. (2011). Coordinate Metrology Education Using Virtual CMM, Annals of DAAAM for 2011 \& Proceedings of the 22nd International DAAAM Symposium, ISBN 978-3-901509-83-4, ISSN 1726-9679, pp 1323-1324, Editor B[ranko] Katalinic, Published by DAAAM International, Vienna, Aus-tria 2011.

[3] KOSTURIAK, J., GREGOR, M., MIČIETKA, B., MATUZSEK, J. (2000). Projektovanie výrobných systémov pre 21. storočí, Žilinská univerzita, 2000, pp. 397, ISBN 80-7100-553-3

[4] FIALA, P. (2004). Projektové ř́zení, modely, metody, analýzy. Professional Publishing, 2004, pp. 276, ISBN 8086419-24-X

[5] GÜNTHER, H.-O., TEMPELMEIER, H. (2006). Übungsbuch Produktion ung Logistik. Springer, 2006, pp. 248, ISBN 3-540-25704-7

[6] STASIAK-BETLEJEWSKA, R. (2010). Construction Product Quality Improvement with Applying Production Problems Analysis. In Manufacturing Technology. Vol. 15, No. 5, ISSN 1213-2489

[7] BORKOWSKI, S., STASIAK-BETLEJEWSKA, R. (2010). Analysis of anti-corrosion coating process on steel constructions. In Manufacturing Technology. Vol. 10, No. 10, pp.27 - 29. ISSN 1213-2489 